\title{
Tanggapan Terhadap Kristologi Saksi Yehuwa Kristus adalah Ciptaan Yang Pertama Berdasarkan Kolose 1:15
}

\author{
Deky Nofa Aliyanto ${ }^{1)^{*}}$ \\ ${ }^{1}$ Sekolah Tinggi Teologi Berea Salatiga \\ ${ }^{*}$ Email : dekytheo@gmail.com
}

Diterima:05 Okt. 2019 / Direvisi:15 Nov. 2019 / Disetujui:04 Des. 2019

\begin{abstract}
Abstrak
"Kristus adalah Ciptaan yang Pertama" merupakan doktrin Kristologi yang diyakini oleh saksi Yehuwa yang dibangun terutama dari Kolose 1: 15. Meyakini Yesus Kristus sebagai ciptaan pertama yang diciptakan oleh Allah, maka pada saat yang bersamaan menolak bahwa Yesus Kristus sepenuhnya Allah. Penelitian ini bertujuan untuk menanggapi Kristologi dari Saksi Yehuwa tersebut dengan cara menginterpretasi Kolose 1: 15 dengan menggunakan metode riset Teologi biblika yaitu pendekatan hermeneutik dan pengkajian Alkitab untuk memahami makna teks dalam konteks penulis mula-mula. Hasil dari penelitian ini menunjukan bahwa દikஸ̀v menyatakan Kristus dalam wujud manusia memiliki kesetaran dengan

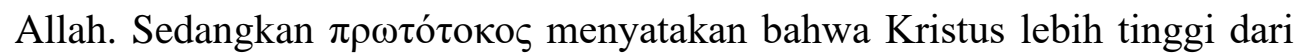
segala yang diciptakan. Kristus bukan diciptakan pertama kali oleh Allah sebagaimana Kristologi saksi Yehuwa.
\end{abstract}

Kata Kunci: Saksi Yehuwa, Kristologi, Gambar, Ciptaan Pertama.

\section{Abstract}

"Christ was The First of Gods Creations" is a Christological doctrine that is believed by Jehovah's witnesses was concepted from Colossians 1: 15. Believing that Jesus Christ as the first creation by God, at the same time rejecting that Jesus Christ is fully God. This study aims to respond to the Christology of Jehovah's witnesses by interpreting Colossians 1:15 using 
the Biblical theology research. This method is a kind of hermeneutic approach and Bible study to understand the meaning of the text in the context of the original author. The results of this study show that Eikiv states that Christ in human form has equality with God. Whereas $\pi \rho \omega \tau$ toкоৎ states that Christ is superior to all that was created. Christ was not first created by God as the Christology of Jehovah's witness. Keywords: Jehovah's Witnesses, Christology, Picture, First Creation.

\section{Pendahuluan}

Saksi Yehuwa tersebar di mana-mana dan ada disekitar kita. Mereka sangat bersemangat dalam memberitakan Kerajaan Yehuwa meskipun berjalan kaki ataupun naik sepeda. Mereka didukung literatur-literatur dengan design yang memukau mata bagi siapa saja yang melihatnya. Tidak hanya itu, literatur-literatur yang berisi doktrin yang mereka percayai tersusun secara sistematis sehingga sekilas lalu mudah dipahami. Mereka juga secara terang-terangan mengidentikan diri sebagai orang Kristen. Persoalnya, siapakah sebenarnya mereka yang menyebut diri sebagai Saksi Yehuwa? Berdasarkan Website resminya, mereka mendeklarasikan diri sebagai berikut, "Kami berasal dari ratusan etnik dan bahasa, tapi kami semua dipersatukan karena tujuan yang sama. Yang terutama, kami ingin menghormati Yehuwa, Allah dalam Alkitab dan Pencipta segala sesuatu. Kami berupaya untuk mengikuti Yesus Kristus dan kami bangga disebut Kristen. Kami semua secara rutin membantu orang-orang belajar tentang Alkitab dan Kerajaan Allah. Karena kami bersaksi, atau berbicara, mengenai Allah Yehuwa dan Kerajaan-Nya, kami dikenal sebagai SaksiSaksi Yehuwa."1 Sehubungan dengan deklarasi tersebut, House mengatakan bahwa para anggota Saksi Yehuwa menganggap diri sebagai satu-satunya organisasi Kristen sejati. Mereka memandang diri mereka sebagai umat Allah yang benar namun yang teraniaya oleh pemerintah serta oleh semua orang Kristen tradisional (dunia Kristen yang murtad). ${ }^{2}$

Deklarasi tersebut menarik karena ternyata mereka berupaya untuk mengikuti ajaran Kristus dan bangga disebut Kristen sejati. Dalam literatur

\footnotetext{
${ }^{1}$ https://www.jw.org/id/. Diakses tanggal 23 Januari 2019 jam 09:00 Wib.

${ }^{2} \mathrm{H}$. Wayne House, Charts of Cults, Sects and Religious Movements (Malang: Gandum Mas, 2006), 175.
} 
lain yang telah terbit, mereka mengharuskan para pengikutnya untuk belajar dari Sang Guru Agung, yaitu Yesus Kristus dan meneladaninya. Literatur itu berjudul "Belajarlah Dari Sang Guru Agung", yang berisi 48 pasal di mana semua tema berasal dari hidup dan ajaran Yesus yang bersumber dari Alkitab. Bahkan tema dalam pasal pertama berjudul "Mengapa Yesus adalah Sang Guru Agung?" 3, yang menjelaskan dua alasan mendasar mengapa Yesus Disebut Sang Guru Agung karena Yesus pernah tinggal di surga sebelum dilahirkan di Bumi dan Yesus sangat mengasihi manusia. ${ }^{4}$

Selain itu, mereka juga menerbitkan literatur yang berisi pokok-pokok Doktrin dengan judul "Apa Yang Sebenarnya Alkitab Ajarkan?", di mana pasal keempat dari literatur tersebut bertema "Siapakah Yesus Kristus." Pasal itu menjelaskan bahwa, "Yesus adalah Putra yang paling Yewuha kasihi - dan ada alasan yang kuat untuk itu. Ia disebut "yang sulung dari antara semua ciptaan", sebab ia adalah ciptaan Allah yang pertama (Kolose 1:15). Karena diciptakan maka Putra memiliki permulaan, sedangkan Allah Yewuha tidak punya awal atau akhir." 5 Kepercayaan tersebut juga ditegaskan dalam buku yang telah mereka terbitkan dengan judul "Jehovah's Withnesses In The $20^{\text {th }}$ Century". 6 Persoalannya, meyakini Yesus Kristus sebagai ciptaan pertama yang diciptakan oleh Allah berarti menolak bahwa Yesus Kristus sepenuhnya Allah. Doktrin Kristologi saksi Yehuwa tersebut jelas-jelas berbenturan dengan doktrin Kekristenan tradisional yang mengakui bahwa Yesus sepenuhnya adalah Allah dan sepenuhnya adalah manusia. Kesaksian Alkitab juga menunjukan bahwa Yesus Kristus adalah Alfa dan Omega, Yang Awal dan Yang Akhir.

Dalam menafsirkan Alkitab, saksi Yehuwa berpatokan pada prinsip bahwa setiap ayat memiliki penilaian yang sama, tidak peduli oleh siapa diucapkan mula-mula, kepada siapa, di mana, pada zaman yang mana, atau dalam keadaan bagaimana. Setiap ayat harus ditafsirkan secara harfiah, tidak peduli apakah itu bentuk syair atau kiasan dan sebaliknya. Ayat-ayat dipetik satu-satu, lepas dari hubungan kalimat, lalu dipaksakan berderet

${ }^{3}$ Learn from The Great Teacher: Belajarlah Dari Sang Guru Agung (Jakarta: Saksi-Saksi Yehuwa Indonesia, 2016), 10.

${ }^{4}$ Learn from The Great Teacher, 10 2013), 41.

${ }^{5}$ Apa Yang Sebenarnya Alkitab Ajarkan (Jakarta: Saksi-Saksi Yehuwa Indonesia,

${ }^{6}$ Jehovah's Withnesses In The $20^{\text {th }}$ Century (Brooklyn, New York: Wacthtower Bible and Tract Society, International Bible Students Association, 1978), 13. 
kembali secara kaku menjadi suatu rentetan bukti-bukti yang menyokong kepercayaan yang dianut. ${ }^{7}$ Berdasarkan prinsip penafsiran ini, maka penulis melihat ada ketidaktepatan yang dilakukan oleh saksi Yehuwa dalam memahami Kolose 1:15, bertolak dari penafsiran ayat tanpa menggunakan prinsip-prinsip hermeneutik yang baik.

Dalam beberapa penelitian sebelumnya, yang berkaitan dengan tema "saksi Yehuwa", disajikan kajian-kajian yang sifatnya lebih umum. Misalnya artikel yang berjudul "Kedudukan Yesus Dalam Ajaran Kristen Saksi Yehuwa", yang ditulis oleh Roni Ismail dalam Jurnal Ilimiah Sosiologi Agama dan Perubahan Sosial UIN Sunan Kalijaga Yogyakarta, ${ }^{8}$ di mana penelitian ini lebih menyoroti masalah siapa dan bagaimana Yesus menurut pandangan saksi Yehuwa. Dalam tulisan tersebut, teks Kolose 1:15 hanya disinggung tanpa suatu telaah yang lebih mendalam dari sisi biblika. Artikel lain yang berjudul "Studi Eksegetis Yohanes 1:1-18 Sebagai Apologetik Terhadap Kristologi Saksi Yehuwa” yang ditulis oleh Pangeran Manurung dalam Jurnal Keruso, Jurnal Teologi dan Pelayanan Sekolah Tinggi Teologi Injili Indonesia Surabaya, membahas tentang keberadaan kelompok saksi Yehowa yang dijelaskan dari sisi biblika, dengan memakai teks Yohanes 1: 1-18. ${ }^{9}$ Berikutnya adalah artikel dengan judul "Kontradiksi Kehadiran Saksi-Saksi Yehuwa Sebagai Denominasi Kristen Di Yogyakarta", yang ditulis oleh Arifudin Ismail dalam Jurnal "Analisa." Artikel ini memfokukan pembahasannya mengenai keberadaan Saksi Yewuha di Yogyakarta. ${ }^{10}$

\footnotetext{
${ }^{7}$ Bagaimana Menghadapi Saksi Yehuwa: Anda Pasti Menemukan Jawabanya (Bandung: Lembaga Literatur Baptis, 1996), 27.

${ }^{8}$ Rony Ismail, Kedudukan Yesus Dalam Ajaran Kristen Saksi Yehuwa. Jurnal Ilimiah Sosiologi Agama dan Perubahan Sosial UIN Sunan Kalijaga Yogyakarta. Vol. 11, No. 2, Juli-Desember 2017/ISSN: 1978-4457 (p), 2548-477X (o).

${ }^{9}$ Pangeran Manurung, Studi Eksegetis Yohanes 1:1-18 Sebagai Apologetik Terhadap Kristologi Saksi Yehuwa. Keruso, Jurnal Teologi dan Pelayanan Vol 1 No 2: Journal Kerusso - September 2016. http://jurnal.sttiisurabaya.ac.id/index.php/Kerusso/article/view/49. Diakses tanggal 10 Oktober 2019 jam 09:00 Wib.

${ }^{10}$ Arifudin Ismail, Kontradiksi Kehadiran Saksi-Saksi Yehuwa Sebagai Denominasi Kristen Di Yogyakarta. Jurnal “Analisa” Volume 19 Nomor 01 Juli Desember 2012. https://media.neliti.com/media/publications/41993-ID-the-contradictionof-the-presence-of-jehovahs-witnesess-as-christian-denominatio.pdf. Diakses tanggal 10 Oktober 2019 jam 09:00 Wib.
} 
Diharapkan artikel yang penulis sajikan saat ini, dengan judul "Tanggapan Terhadap Kristologi Saksi Yehuwa "Kristus adalah Ciptaan Yang Pertama" Berdasarkan Interpretasi Kolose 1: 15" dapat memberi sumbangsih yang semakin memperlengkapi artikel-artikel sebelumnya tentang kelompok saksi Yehuwa, karena artikel ini akan meneliti dua hal penting, yaitu pertama, perkembangan saksi Yehuwa yang cukup pesat berpotensi mereduksi keyakinan Kristologi umat Kristen ketika berdikusi tentang Kristologi dengan mereka. Kedua, penelitian ini dapat menjadi suatu bahan belajar untuk memahami secara tepat maksud dari Kolose 1: 15.

\section{Metode Penelitian}

Penelitian ini menggunakan metode kualitatif, dengan pendekatan Teologi biblika yang mencakup pendekatan hermeneutik untuk sastra surat. Pengkajian Alkitab yang demikian bertujuan memahami makna teks dalam konteks penulis mula-mula. ${ }^{11}$ Oleh sebab itu cara ini digunakan untuk menemukan maksud penulis mula-mula tentang Kristus dalam Kolose 1:15. Ketika maksud penulis mula-mula diketemukan, maka secara otomatis akan terlihat ketidaktepatan dari saksi Yehuwa memahami ayat tersebut.

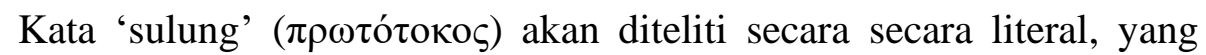
bisa berarti as the oldest son in a family (Lukas 2.7; Ibrani 11.28). ${ }^{12}$ atau being the first child in order of birth, firstborn (Matius 1:25; Lukas 2:7; Ibrani 11:28). ${ }^{13}$ We usually associate the term firstborn with birth and it connotes to us the first child. This meaning occurs in Luke 2:7; Jesus is the

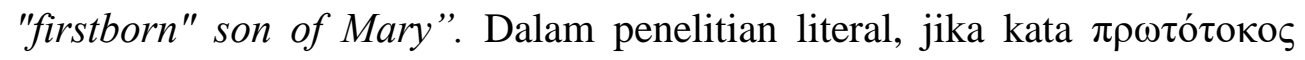
dalam Kolose 1:15 dilepaskan dari konteksnya serta tidak memerhatikan ayat-ayat di sekitarnya dalam tugas interpretasi, akan menimbulkan kesan bahwa Yesus Kristus adalah ciptaan yang pertama. Itulah sebabnya terjemahan harfiah 'yang sulung dari segala ciptaan' menimbulkan arti

${ }^{11}$ Hermeneutik adalah interpretasi teks atau makna tertulis yang mengharuskan peneliti kembali berulang-ulang ke sumber data, mengadakan dialog dengan sumber data, mencoba memahami makna bagi penulis mula-mula, dan mecoba mengintegrasikannya dengan makna bagi peneliti. Andreas B. Subagyo, Pengantar Riset Kuantitatif dan Kualitatif (Bandung: Kalam Hidup, 2004), 118.

12 Timothy Friberg and Barbara Friberg. BibleWorks, v.10.

${ }^{13}$ F. Wilbur Gingrich, Shorter Lexicon Of The Greek New Testament. 2nd ed. Frederick W. Danker (Chicago: University of Chicago Press, 1983), BibleWorks. v.10. 
bahwa Kristus termasuk dalam alam semesta yang diciptakan. ${ }^{14}$ Beberapa orang (termasuk para pengikut Arius) berpendirian bahwa kata itu harus dimengerti berdasarkan Amsal 8:22, dan mereka menafsirkan ayat tersebut dengan arti bahwa Hikmat itu diciptakan. ${ }^{15}$ Implikasi dari pendirian ini serupa dengan keyakinan saksi-saksi Yehuwa bahwa Christ Was First Of God's Creations.

Metode yang sama juga akan digunakan untuk memahami kata

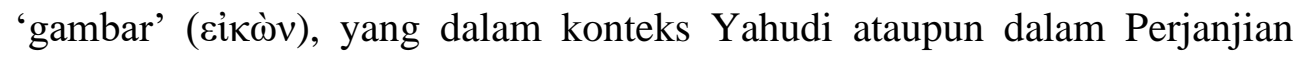
Lama merupakan kata yang kurang tepat, karena secara kaku akan bertentangan dengan urutan pertama dari sepuluh perintah Allah “...Jangan ada padamu allah lain di hadapan-Ku" (Keluaran 20:3). Itulah sebabnya dalam konteks Yahudi pemahaman bahwa sikcòv memanifestasikan wujud asli dalam kesetaraan adalah asing. Kata દikஸ̀v yang digunakan Rasul Paulus dalam Kolose 1:15 merupakan istilah adopsi dari konteks Yunani, di mana દǐฒ̀v memanifestasikan wujud asli secara setara sehingga dalam konteks Yunani inilah makna dari Eikòv lebih tepat dipahami untuk memahami Kolose 1: 15.

\section{Pembahasan}

\section{Tafsiran Kolose 1:15}

Epafras diyakini sebagai pendiri dari jemaat Kolose. Sebab dalam pasal 1:7, Rasul Paulus menyatakan, "Semuanya itu telah kamu ketahui dari Epafras, kawan pelayan yang kami kasihi, yang bagi kamu adalah pelayan Kristus yang setia". Sedangkan pasal 4:12-13, Epafras disebut 'seorang dari antaramu' yang berarti ia adalah orang Kolose, dan Paulus menyaksikan susah payahnya bagi jemaat di kotanya dan bagi orang Kristen di Lembah Likus, di mana Epafras mungkin tidak bisa menjawab argumentasi dari guru-guru palsu sehingga memerlukan hikmat yang lebih besar dari Paulus. ${ }^{16}$ Berdasarkan maksud inilah Rasul Paulus kemudian menulis surat

${ }^{14}$ Bratcher dan Eugene A. Nida, 22. Bandingkan juga penjelasan kata $\pi \rho \omega \tau$ ó $\tau$ око $\varsigma$ ini dengan tulisan Deky Nofa Aliyanto, "Kajian Biblika Yesus Kristus Saksi yang Setia dalam Wahyu 1:5 dan Relevansinya Bagi Gereja Abad 1, Fidei: Jurnal Teologi Sistematika dan Praktika, Vol. 1, No. 2, 2018, 100-101.

${ }^{15}$ Donald Guthrie, New Testament Introduction: Pengantar Perjanjian Baru

Volume 2, (Malang: Momentum, 2013), 404.

${ }^{16}$ Guthrie, 152. 
kepada jemaat Kolose. Menurut Barclay, "Jelaslah bahwa Gereja Kolose sebagian besar terdiri dari orang-orang bukan Yahudi". ${ }^{17}$

Ajaran palsu yang disebabkan oleh bidat adalah persoalan yang dihadapi oleh jemaat di Kolose. Pengajar sesat ini adalah orang-orang Yahudi berkebudayaan Yunani yang menganut ajaran gnostik. Ciri ajaran mereka (spekulasi kosmis dan asketisme) cenderung kepada spekulasi gnostik. ${ }^{18}$ Paulus menulis untuk memberantas ajaran palsu yang berbahaya di Kolose yang sedang menggantikan keunggulan Kristus dan kedudukanNya sebagai inti dalam ciptaan. ${ }^{19}$ Dalam beberapa hal pengajaran sesat ini merendahkan pribadi Kristus, karena Paulus sangat meninggikan keutamaan Kristus (psl. 1:15-19). ${ }^{20}$ Tampak jelas disini adalah suatu bidat yang menyerang ajaran tentang sifat yang secara menyeluruh memadai (total adequancy) dan keunggulan yang unik di dalam diri Kristus. ${ }^{21}$ Bukan hanya dalam teks tersebut, nampaknya 'Keutamaan Kristus' merupakan tema sentral dalam surat Kolose seperti diyakini Tenney dalam ikhtisar surat Kolose. ${ }^{22}$ Surat Kolose juga berisi satu perikop yang serupa tentang

${ }^{17}$ Frase yang berkata 'yang dahulu hidup jauh dari Allah dan memusuhi-Nya dalam hati (1: 2) adalah frase yang kerap kali dipakai Paulus bagi mereka yang dulunya tidak mengenal perjanjian Allah dengan Israel. Dalam Kolose 1:27 ia berbicara tentang memberitahukam rahasia Kristus di kalangan orang-orang Kafir yang rujukanya cukup jelas yaitu orang Kolose. Dan dalam Kolose 3:5-7 ia memberi daftar dosa mereka sebelum menjadi Kristen dan dosa-dosa itu merupakan dosa-dosa khas orang Kafir. William Barclay, Pemahaman Alkitab Setiap Hari: Surat Filipi, Kolose, 1 dan 2 Tesalonika (Jakarta:BPK Gunung Mulia, 2006), 146.

${ }^{18}$ Para guru palsu ini memiliki minat yang besar terhadap kuasa-kuasa alam atau unsur roh-roh alam (2:8). Unsur-unsur roh kosmis ini dipercayai sebagai mahluk-mahluk ilahi yang mengatur alam semesta. Roh-roh ini disembah dan dilayani. Penyembahan kepada malaikat-malaikat (2:18) nampaknya memiliki hubungan dengan pemerintahpemerintah dan penguasa-penguasa yang disebutkan dalam Kolose 2:15. Para guru palsu ini percaya bahwa melalui hubungan yang cocok atau sesuai dengan kuasa-kuasa kosmos ini, maka kepenuhan pengalaman ilahi terwujud. Sebagai pemilik misteri kosmos, guru-guru palsu ini menyatakan bahwa mereka memiliki penglihatan-penglihatan khusus (2:18) dari yang Ilahi. Dan kemudian membangga-banggakan pengetahuan agama itu.

Samuel Benyamin Hakh, Perjanjian Baru: Sejarah, Pengantar dan Pokok-Pokok Teologisnya (Bandung: Bina Media Informasi), 217.

${ }^{19}$ Alkitab Penuntun Hidup Berkelimpahan (Malang: Gandum Mas, 2009), 1087.

${ }^{20}$ Gutrie, 152

${ }^{21}$ Gutrie, 147.

22 Merrill C. Tenney, Survei Perjanjian Baru (Malang: Gandum Mas, 2003), 399. 
keunggulan mutlak dari Kristus yang mengatasi alam Semesta. ${ }^{23}$ Secara khusus Karkkainen menjelaskan, "According to colossians, 'christ is all, and is in all' (chapter 3: 11). Famous is the comment of J.B. Lightfoot, the great new testament theologian of nineteenth century: the doctrine of the person of Christ is here (in Colossians) stated with greather precision and fullness than in any others of St. Paul's epistles. ${ }^{24}$

Berdasarkan pandangan dari para ahli maka 'Keutamaan Kristus' tidak mungkin bisa dilepaskan dari konteks historis surat Kolose, terutama Kolose 1:15-19. Oleh sebab itu interpretasi terhadap Kolose 1:15 tidak mungkin bisa dilepaskan dari tema 'Keutamaan Kristus' serta ajaran sesat yang pada waktu itu sedang berkembang dan dilawan oleh sang rasul yang merendahkan Kristus dan menyesatkan jemaat Kolose. Bagian ini (ay. 1520) sering disebut sebagai sebuah nyanyian atau 'kidung' yang menggambarkan tentang pribadi dan karya Kristus." 25 Karkkainen menyatakan, "The hymnic passage in 1:15-20 has two parts. Verses 15-18, tell us that Christ is the image of the unseen God and the beginning of all creation because all things were created in him. Christ is also the head of the church."26 Menurut Wright, seperti dikutip oleh Garland, "another disputed issue concern the structure of the poem. I divide into two strophes." 27 Ayat 15 merupakan bagian pertama berdasarkan dua pembagian itu dan Fee membuat struktur pemikiran Paulus dalam ayat 15 sebagai berikut:

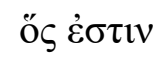

घi்ஸ̀v

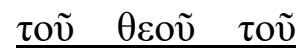

גopótov,

ő $\tau$

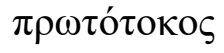

$\dot{\varepsilon} \vee \alpha \hat{\tau} \tilde{\omega}$ $\pi \alpha ́ \sigma \eta \varsigma \kappa \tau i ́ \sigma \varepsilon \omega \varsigma$.

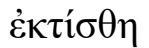

$\tau \grave{\alpha} \pi \alpha ́ \alpha \tau \alpha$, 2007), 56.

${ }^{23}$ John Stott, The Incomparable Christ: Kristus Yang Tiada Tara (Momentum,

${ }^{24}$ Veli - Matti Karkkainen mengutip pandangan J.B. Lightfoot dalam Veli - Matti Karkkainen, Christology A Global Introduction: An Ecumenical, International and Contextual Perspective (Michigan: Baker Academic, 2003), 55-56.

${ }^{25}$ Robert G. Bratcher dan Eugene A. Nida, Pedoman Penafsiran Alkitab: SuratSurat Paulus Kepada Jemaat di Kolose dan Kepada Filemon (Jakarta: Lembaga Alkitab Indonesia dan Yayasan Karunia Bakti Budaya Indonesia, 2014), 22.

${ }^{26}$ Karkkainen, 56.

${ }^{27}$ David E. Garland, The NIV Aplication Commentary: Colossians/Philemon (Michigan: Zondervan Grand Rapids, 1998), 85. 


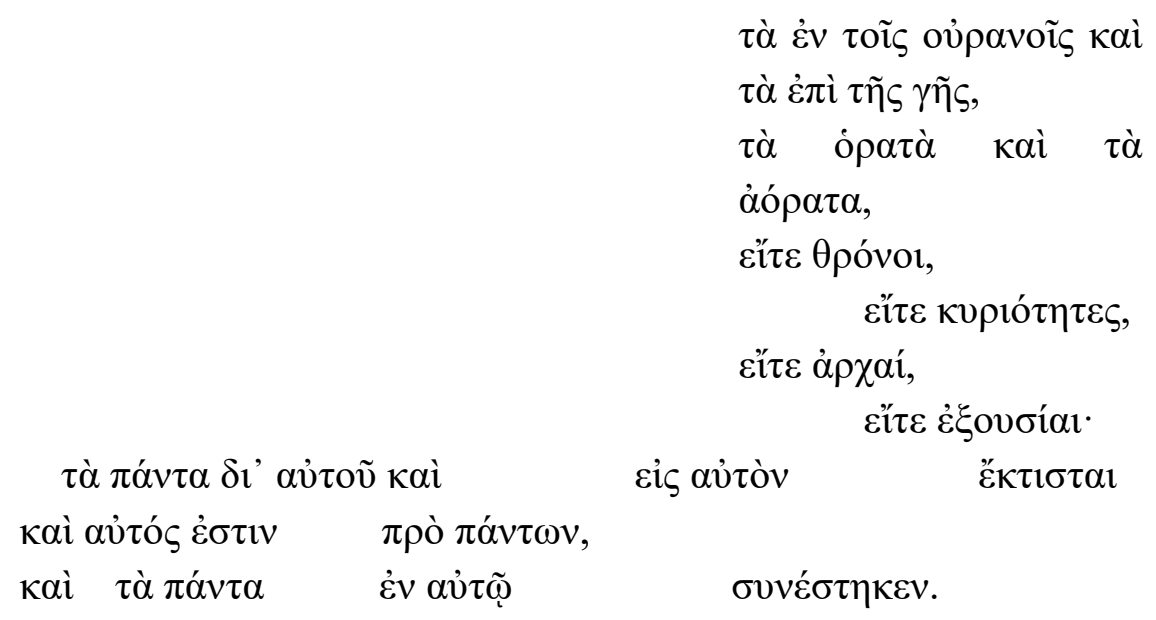

Who is the image

of God, the invisible

$\underline{\text { God }}$

invisible

the firstborn

because in Him over all creation,

were created all things

in heavens and on earth

things visible and

loardship

whether trones or

whether rulers

or

authorities

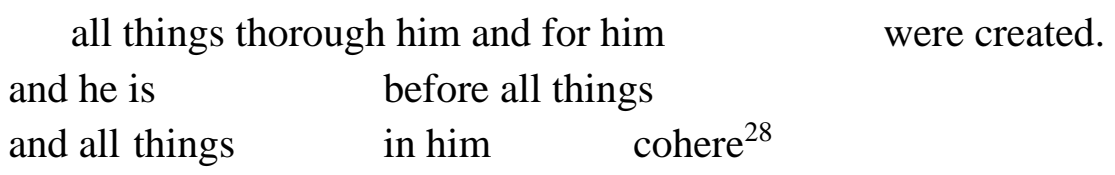

Berdasarkan pembagian yang dinyatakan beberapa pakar, penafsiran yang ideal seharusnya mencakup ayat $15-18$, namun tulisan ini membatasi hanya menafsirkanayat 15 dengan alasan, pertama, meskipun hanya ayat 15 namun tulisan ini juga akan menyinggung ayat sebelum dan sesudahnya dalam konteks kitab Kolose. Kedua, menafsirkan ayat 15 sudah mewakili

${ }^{28}$ Gordon D. Fee, Pauline Christology: An Exegetical - Theological Study (Massachusetts: Hendrickson Publishers), 2007), 300. 
untuk meluruskan Kristologi saksi Yehuwah bahwa Christ Was First Of God's Creations karena memang disinilah letak persoalanya. Berdasarkan ayat tersebut, tulisan ini akan menafsirkan frase penting yang berkaitan

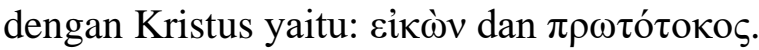

\section{Eikon: Gambar}

Kata 'gambar' diterjemahkan dari kata દikஸ̀v, yang berarti an image, figure, likeness. Kata cikஸ̀v juga digunakan beberapa kali dalam Perjanjian Baru, yaitu Matius 22:20; Kolose 1:15 dan Ibrani 10:1. Menurut Friberg dalam konteks Matius 22:20 "Eikผ̀v as an artistic representation, such as on a coin or statue image, likeness. ${ }^{29}$ Dalam Kolose 1:15 diartikan as an embodiment or living manifestation of God form, appearance. Sedangkan dalam Ibrani 10:1 diartikan as a visible manifestation of an invisible and heavenly reality form, substance. ${ }^{30}$ Dunia Perjanjian Baru menegaskan bahwa yang asli hadir dalam gambar, yang memberikan manifestasi yang

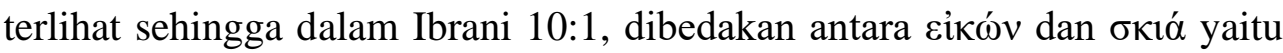
bayangan, ${ }^{31}$ dan LAI menerjemahkan Eikòv sebagai hakikat. Barclay, mengutip Lightfoot, mengatakan, "Sebuah gambar berarti dua hal yang saling bergabung. Gambar dapat berupa representasi, tetapi suatu representasi, apabila benar-benar sempurna, dapat menjadi suatu manifestasi. Paulus memakai kata ini untuk mengatakan bahwa Yesus adalah manifestasi Allah yang sempurna." 32

Menurut Kleinknecht, cikஸ̀v adalah in popular Greek religion, the god is present in the image, as is shown by the miracles and magic associated with images. The copies have the same powers, feelings, etc. as the originals. Rulers are also gods in visible manifestation. ${ }^{33}$ Senada dengan ungkapan tersebut Garland mengatakan in greek philosophy, however, the

${ }^{29}$ Timothy Friberg and Barbara Friberg. Analytical Greek New Testament (GNM).

2nd ed. Timothy and Barbara Friberg, 1994. BibleWorks, v.10.

${ }^{30}$ Friberg.

${ }^{31}$ Gerhard Kittel, Gerhard Friedrich, and Geoffrey W. Bromiley, Theological Dictionary of the New Testament (Abridged) (Grand Rapids: Eerdmanns, 1985),

BibleWorks, v.10.

${ }^{32}$ Barclay, 177-178.

${ }^{33}$ Penjelasan dari H. Kleinknecht dikutip oleh Gerhard Kittel, Gerhard Friedrich, and Geoffrey W. Bromiley, Theological Dictionary of the New Testament (Abridged) (Grand Rapids: Eerdmanns, 1985), BibleWorks, v.10. 
image has a share in the reality that it reveals and may be said to be reality An image was not consedered something distinct from the object it represented, like a facsimile or reproduction. ${ }^{34}$ Tujuan dari penggunaan kata દikஸ̀v yang demikian adalah untuk memberantas ajaran palsu yang berbahaya di Kolose yang sedang menggantikan keunggulan Kristus dan kedudukan-Nya sebagai inti dalam ciptaan melawan ajaran palsu di Kolose. Pengajar sesat ini adalah orang-orang Yahudi berkebudayaan Yunani yang menganut ajaran gnostik. ${ }^{35}$ Sebagaimana keterangan dalam Kolose 2:16-23, nampaknya jemaat Kolose terjebak untuk menyembah ciptaan termasuk malaikat.

Frasa dalam Kolose 1:15 dan 2 Korintus 4:4 memiliki penekanan pada kesetaraan Eikòv dengan yang asli. Kristus dalam rupa Allah dan setara dengan Allah (lih. Filipi 2:6). MelihatNya berarti melihat Bapa (Yohanes 14:9), Putra Terkasih dalam Kol 1:13. ${ }^{36}$ Senada dengan Friberg dan Kittel, dengan gamblang Gutrie menerangkan bahwa melalui penggunaan kata 'gambar' (eikon) sebenarnya Paulus sedang menegaskan bahwa Kristus adalah penyataan Allah yang sempurna. Baik agama Yahudi maupun Kekristenan menegaskan bahwa Allah tidak kelihatan dan sebagai akibatnya menolak penyembahan berhala, tetapi hanya iman Kristen yang mengenal yang tidak kelihatan itu melalui rupa-Nya yang sempurna di dalam Kristus. Penggunaan yang sama dari kata 'gambar' (eikon) ditemukan juga dalam 2 Korintus 4:4 yang berhubungan dengan kemuliaan Kristus dalam Injil. ${ }^{37}$ Tekanan dari Gutrie bahwa Kristus adalah pernyataan Allah yang sempurna juga ditegaskan oleh Fee bahwa Kritus adalah gambar Allah yang sejati. Sebagai gambar Allah, Kristus adalah representasi Allah yang tepat,

${ }^{34}$ Garland, 87.

${ }^{35}$ Gambaran jemaat Kolose terlihat melalui penduduk kota Kolose terdiri dari berbagai bangsa. Sebagian besar warga kota adalah orang pribumi Frigia, yang terkenal sebagai penganut Klenik (mistik) dan bersifat tidak mantap. Sejumlah besar orang Yunani juga menghuni kota itu. Bahasa Yunani dan kebudayaan menonjol di lembah Lycus. Di Kolose terdapat sebuah perkampungan orang Yahudi yang agak besar. Banyak di antara mereka telah menyimpang dari sifat ortodok dalam agama Yahudi. Jarry Autrey, Surat Kiriman Penjara (Malang: Yayasan Penerbit Gandum Mas, 2001), 154.

${ }^{36}$ Gerhard Kittel, Gerhard Friedrich, and Geoffrey W. Bromiley, BibleWorks, v.10.

${ }^{37}$ Donald Gutrie, Teologi Perjanjian Baru 1: Allah, Manusia, Kristus (Jakarta: BPK Gunung Mulia, 2009, 403. 
sekaligus terlihat, sebagai representasi Allah. (Kol 1:19; 2:9). ${ }^{38}$ Senada dengan Fee, Garland menegaskan, "As the image of God, christ is an exact, as well as a visible, representation of God (Colossians 1:19; 2:9), illuminating God's essence." 39

Menurut Eaton, Yesus dan Bapa adalah setara dalam keillahian, itulah sebabnya untuk mengenal Allah maka manusia harus mengenal Yesus. Eaton menatakan, "Jesus in the "image of invisible God". God the father is invisible. But the father has found a way to make Himself visible. His sent His son, who has an identical character and an identical divine nature. The son became a man and the divine character appeared in human form. "He who has seen me has seen the father" said Jesus. If you want to know what God is like, look at jesus. When you see the way Jesus treated people, you are seeing the way God the father treats people. When you see Jesus righteousness and purity and wisdom, you may know that He is everithing that the Father is, in human form. If the Father is God, Jesus is God - but in visible. $^{40}$

Bagi Wright, Keabadian Yesus, yang pada hakikatnya telah menjadi gambar Allah, dengan sempurna mencerminkan karakter dan kehidupan sang ayah. Karena itu pantas baginya untuk menjadi gambar Allah sebagai manusia; dari segala kekekalan Yesus memiliki hubungan yang sama dengan ayah yang manusia inginkan, sejak penciptaannya, dimaksudkan untuk melahirkan. ${ }^{41}$ In Christ God shows us his righteosness, goodness, wisdom, power, in short, his entire self. ${ }^{42}$

Berdasarkan pendapat beberapa ahli tersebut dapat ditarik kesimpulan bahwa istilah عikஸेv harus dipahami dalam konteks teologis dan filosophis masyarakat Yunani yang menyatakan bahwa عìkòv memanifestasikan wujud asli dari yang ilahi dalam kesetaraan. Pemahaman cìcòv yang demikian,

${ }^{38}$ Fee, 299.

${ }^{39}$ Garland, 87.

${ }^{40}$ Michael Eaton, Preaching Through the Bible: Colossians (Tonbridge, Sovereign Worl, 2005), 39.

${ }^{41}$ N. T. Wright, Tyndale New Testament Commentaries: Colossians and Philemon (Grand Rapids: William B. Eerdmans Publishing Company), 70.

${ }^{42}$ Kalimat tersebut adalah pernyataan dari Calvin dalam buku Calvin, Commentaries on The Epistels of Paul The Apostle to The Philippians, Colosisian and Thesalonians, 150. Yang dikutip oleh David E. Garland, The NIV Aplication Commentary: Colossians/Philemon, 87. 
diadopsi oleh Rasul Paulus untuk menunjukan keutamaan Kristus yang kemudian digunakan sebagai senjata untuk melemahkan ajaran palsu yang berkembang dalam Jemaat Kolose. Pemakaian eìஸ̀ेv dalam Kolose 1:15 menunjukan relasi antara Yesus dengan Allah Bapa dimana dalam relasi tersebut keduanya adalah setara dalam keilahian namun pribadi yang berbeda.

\section{Prototokos: Sulung}

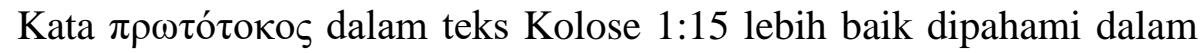
arti bahwa Kristus lebih tinggi dari dari segala yang diciptakan. Dalam Pemikiran Ibrani dan Yunani, kata 'yang sulung' ( $\pi \rho \omega \tau$ ó pada pengertian yang tidak selalu berkait langsung dengan urutan waktu. ${ }^{43}$ Menurut Keaner, dalam agama Yunani dan Yahudi tuhan atau dewa sebagai yang tertinggi adalah yang pertama. ${ }^{44}$ Menariknya, bagi Garland itu tidak berarti bahwa Kristus adalah yang pertama diciptakan atau dilahirkan. ${ }^{45}$ Teks dalam Bahasa Yunani menunjukan bahwa Yesus disebut sebagai pewaris, yang menduduki peringkat pertama, maka sebelum dan lebih unggul di atas semua ciptaan sebagai Tuhan. Bacaan tersebut memakai $\pi \rho \omega \tau$ ́́ (diciptakan pertama). Efraim disebut 'anak sulung' Allah, namun demikian dalam Kejadian 41:51-52 disebutkan bahwa Manasye secara harfiah yang adalah anak sulung, bukan Efraim. Jelaslah, 'anak sulung' tidak selalu memiliki arti harfiah, yaitu berarti dilahirkan pertama atau diciptakan pertama. ${ }^{46}$ Alkitab tidak pernah menyebutkan bahwa Yesus Kristus adalah ciptaan Allah. Faktanya Ia digambarkan sebagai Pencipta dari semua yang ada (Kolose 1:16). Ia juga disebut sebagai yang sama "kemarin, hari ini, dan sampai selama-lamanya" (Ibrani 13:8).

\footnotetext{
${ }^{43}$ Barclay, 182.

${ }^{44}$ Craig S. Keener, The Bible Backgroud Commentary: New Testament (Illionis: An Imprint of InterVarsity Press), 1993), 527.

${ }^{45}$ In the Old Testament, this title expresses status. It appears in the pslm 89: 27 as a title of sovereignty: I will also appoint him my firstborn, the most exalted of the kings of the earth. God bestowed this title on Israel because of her divine election (ex 4: 22; Isa 64: 8; Jer 31: 9; Psalm of Salomon 18: 4, 4 Ezra 6: 58). the metaphor, therefore, distinguishes christ from all created things as before them in time and as supreme. Paul asserts Christ's primacy over creation. and not just within creation. Lih. Garland, 87.
}

${ }^{46}$ House, 179-180. 


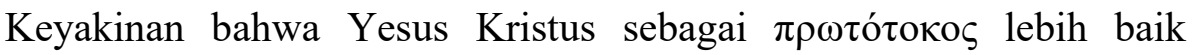
dipahami sebagai lebih tinggi dari segala ciptaan jelas terlihat dalam Kolose 2:17 -18. Menurut Guthrie gagasan 'Kristus lebih tinggi dari segala yang diciptakan' sangat sesuai dengan arah utama dari Kolose 1:15-20 secara keseluruhan, yaitu mengenai keberadaan Kristus yang terlebih dulu ada sebelum segala sesuatu ada. Kristus bukanlah yang terbesar di antara sekian banyak ciptaan lainya, dan tidak ada kesan bahwa Paulus mempunyai pikiran demikian. Dengan jelas ia menempatkan Kristus di atas semua ciptaan dalam pernyataan-pernyataan yang berikutnya. Hal ini dipelihatkan dengan cara yang khusus dalam Kolose 1:16, yang mengatakan bahwa segala sesuatu telah diciptakan 'di dalam Dia' (en auto), 'oleh Dia' (di auton) dan 'untuk Dia' (eis auton). ${ }^{47}$ Pemahaman bahwa Kristus lebih tinggi dari segala ciptaan adalah tepat sesuai dengan konteks Jemaat Kolose yang terjebak untuk menyembah ciptaan dan merendahkan Kristus sebagaimana terlihat dalam Kolose 2:16-23.

Rasul Paulus dalam teks Kolose 1:15 menempatkan Kristus sebagai pusat dari penciptaan dan menegaskan keunggulan-Nya atas ciptaan. Gagasan ini juga diyakini oleh Vaughan dengan mengatakan, "In relation to the universe, christ is 'the firstborn over all creation.' Firstborn (prototokos) is used of christ, in addition to the passage under study, in Colossians 1:18; Romas 8:29; Hebrew 1:16; and either priority in time. or supremacy in rank. In the present passage perhaps we should see both meanings. Christ is before all creation in time; he is also over it in rank and dignity. the major stress, however, seems to be on the idea of supremacy."48 Memang gagasan Vaughan di satu sisi tetap mempertahankan pemahaman bahwa prototokos berbicara mengenai prioritas waktu, namun menurutnya prioritas waktu disini berarti Christ is before all creation in time. Jadi $\pi \rho \omega \tau$ ́́ waktu sebagaimana urutan seorang anak sulung dalam suatu keluarga yang kemudian menempatkan Kristus sebagai ciptaan yang pertama diciptakan

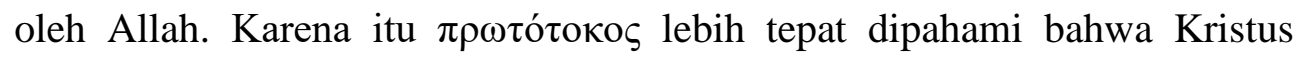
diatas semua ciptaan karena segala sesuatu telah diciptakan di dalam Dia,

${ }^{47}$ Donald Guthrie, New Testament Introduction: Pengantar Perjanjian Baru Volume 2, 404.

${ }^{48}$ Frank E. Gaebelein, The Expositor's Bible Commentary: With International version Volume 11 (Grand Rapids, Michigan: Zodervan Publishing House, 1984), 182. 
oleh Dia dan untuk Dia. Namun demikian jika $\pi \rho \omega \tau$ đó dipahami dalam urutan waktu maka hal ini berarti Yesus adalah pewaris, yang menduduki peringkat pertama sebelum segala sesuatu ada dan diciptakan dan lebih unggul di atas semua ciptaan. Atau dengan ungkapan lain sebelum segala sesuatu ada dan diciptakan Yesus sudah eksis.

\section{Kesimpulan}

Ungkapan Paulus bahwa Yesus Kristus adalah 'Gambar Allah yang tidak kelihatan', tidak tepat dipahami sebagai wakil dari Allah yang secara hakikat lebih rendah dari Allah. Istilah 'Gambar Allah yang tidak kelihatan' memiliki kualifikasi setara dengan yang diwakilinya, atau dengan kata lain Allah dan gambar Allah memiliki kesetaraan yang memiliki kesetaraan dengan-Nya. Dengan makna 'Gambar Allah yang tidak kelihatan', Paulus sebenarnya hendak menunjukan keutamaan dari Yesus Kristus yang direndahkan oleh para bidat yang berkembang pada waktu itu. Yesus Kristus lebih tinggi dari para malaikat (Kolose 2:18), pemerintah dan penguasa (Kolose 2:10). Sebab di dalam Kristus berdiam secara jasmaniah seluruh kepenuhan ke-Allahan (Kolose 2:9).

Kata $\pi \rho \omega \tau$ ó bahwa 'Kristus lebih tinggi dari segala yang diciptakan' sangat sesuai dengan arah utama dari Kolose 1:15-20 secara keseluruhan, yaitu mengenai keberadaan Kristus yang terlebih dulu ada sebelum segala sesuatu ada. Dengan jelas ia menempatkan Kristus di atas semua ciptaan dalam pernyataan-pernyataan yang berikutnya. Hal ini diperlihatkan dengan cara yang khusus dalam Kolose 1:16, yang mengatakan bahwa segala sesuatu telah diciptakan 'di dalam dia' (en auto), 'oleh Dia' (di auton) dan 'untuk Dia' (eis auton). Dengan demikian Kristologi saksi Yehuwa yang menyatakan bahwa Kristus adalah ciptaan yang pertama kali diciptakan oleh Allah tidaklah tepat. 


\section{Daftar Pustaka}

Aliyanto, Deky Nofa, "Kajian Biblika Yesus Kristus Saksi yang Setia dalam Wahyu 1:5 dan Relevansinya Bagi Gereja Abad 1, Fidei: Jurnal Teologi Sistematika dan Praktika, Vol. 1, No. 2, 2018.

Apa Yang Sebenarnya Alkitab Ajarkan. Jakarta: Saksi-Saksi Yehuwa Indonesia, 2013.

Alkitab Penuntun Hidup Berkelimpahan. Malang: Gandum Mas, 2009.

Autrey, Jarry, Surat Kiriman Penjara, Malang: Yayasan Penerbit Gandum Mas, 2001.

Barclay, William, Pemahaman Alkitab Setiap Hari: Surat Filipi, Kolose, 1 dan 2 Tesalonika, Jakarta:BPK Gunung Mulia, 2006.

Bagaimana Menghadapi Saksi Yehuwa: Anda Pasti Menemukan Jawabanya, Bandung: Lembaga Literatur Baptis, 1996.

Bratcher, Robert G., Eugene A. Nida, Pedoman Penafsiran Alkitab: SuratSurat Paulus Kepada Jemaat di Kolose dan Kepada Filemon, Jakarta: Lembaga Alkitab Indonesia dan Yayasan Karunia Bakti Budaya Indonesia, 2014.

Calvin, Comentaris On The Efistles Of Paul The Apostle To The Philippians, Colosisian and Thessalonians,.

Eaton, Michael, Preaching Through the Bible: Colossians, Tonbridge: Sovereign Worl, 2005.

Fee, Gordon D., Pauline Christology: An Exegetical - Theological Study, Massachusetts: Hendrickson Publishers, 2007.

Frank E. Gaebelein, The Expositor's Bible Commentary: With International version Volume 11, Grand Rapids, Michigan: Zodervan Publishing House, 1984.

Friberg, Timothy and Barbara Friberg, Analytical Greek New Testament $(G N M)$. 2nd ed. Timothy and Barbara Friberg, 1994. BibleWorks, v.10.

Garland, David E., The NIV Aplication Commentary: Colossians/Philemon, Michigan: Zondervan Grand Rapids, 1998.

Gingrich, F. Wilbur, Shorter Lexicon Of The Greek New Testament. 2nd ed. Frederick W. Danker, Chicago: University of Chicago Press, 1983), BibleWorks. v.10. 
Guthrie, Donald, New Testament Introduction: Pengantar Perjanjian Baru Volume 2, Malang: Momentum, 2013.

Jakarta: BPK Gunung Mulia, 2009.

Hakh, Samuel Benyamin, Perjanjian Baru: Sejarah, Pengantar dan PokokPokok Teologisnya, Bandung: Bina Media Informasi.

Hayes, John H. dan Carl R. Holladay, Pedoman Penafsiran Alkitab, Jakarta: BPK Gunung Mulia, 2017.

House, H. Wayne, Charts of Cults, Sects And Religious Movements, Malang: Gandum Mas, 2006.

Ismail, Rony, "Kedudukan Yesus Dalam Ajaran Kristen Saksi Yehuwa", Jurnal Ilimiah Sosiologi Agama dan Perubahan Sosial, Vol. 11, No. 2, 2017 (Yogyakarta: UIN Sunan Kalijaga).

Ismail, Arifudin, "Kontradiksi Kehadiran Saksi-Saksi Yehuwa Sebagai Denominasi Kristen Di Yogyakarta", Jurnal Analisa, Vol. 19, No. 01, 2012.

Jehovah's Withnesses In The 20 th Century, Brooklyn, New York: Wacthtower Bible And Tract Society, International Bible Students Association, 1978.

Karkkainen, Veli - Matti, Christology A Global Introduction: An Ecumenical, International and Contextual Perspective, Michigan: Baker Academic, 2003.

Keener, Craig S., The Bible Backgroud Commentary: New Testament, Illionis: An Imprint of InterVarsity Press), 1993.

Kittel, Gerhard., Gerhard Friedrich. and Geoffrey W. Bromiley, Theological Dictionary of the New Testament (Abridged), Grand Rapids: Eerdmanns, 1985. BibleWorks, v.10.

Learn from The Great Teacher: Belajarlah Dari Sang Guru Agung, Jakarta: Saksi-Saksi Yehuwa Indonesia, 2016.

Manurung, Pangeran, "Studi Eksegetis Yohanes 1:1-18 Sebagai Apologetik Terhadap Kristologi Saksi Yehuwa", Keruso: Jurnal Teologi dan Pelayanan, Vol 1 No 2, 2016.

Mounce, William D., Basics of Biblical Greek: Grammar, Zondervan: Grand Rapids Michigan, 2003. 
Subagyo, Andreas B., Pengantar Riset Kuantitatif dan Kualitatif, Bandung: Kalam Hidup, 2004.

Sutanto, Hasan, Hermeneutik: Prinsip dan Metode Penafsiran Alkitab, Malang: Literatur SAAT, 2007.

Stott, John, The Incomparable Christ: Kristus Yang Tiada Tara, Surabaya: Momentum, 2007.

Stuart, Douglas, Eksegese Perjanjian Lama, Malang: penerbit Gandum Mas, 1997.

Tenney, Merrill C., Survei Perjanjian Baru, Malang: Gandum Mas, 2003.

Wright, N.T., Tyndale New Testament Commentaries: Colossians and Philemon, Grand Rapids: William B. Eerdmans Publishing Company. 